\title{
The Continental Shelf Project of the Kingdom of Denmark - status and issues
}

\author{
Christian Marcussen, Finn Mørk, Thomas Funck, Willy Lehmann Weng and Mikael Pedersen
}

This paper summarises the status of the Continental Shelf Project of the Kingdom of Denmark after the recent submission for an extended continental shelf in the area to the north of Greenland. We discuss some of the similarities between the submission areas north of the Faroe Islands and north of Greenland including the morphological continuation of ridges extending seaward of the geomorphical continental shelf. Documentation of the sediment thickness in the adjoining basins and sediment continuity with the continental slope plays a vital role in the delineation of the outer limits of the extended continental shelf. Here, we compare how these issues were addressed around the well-studied Faroe Islands and in the sparsely surveyed Arctic Ocean.

The Kingdom of Denmark ratified the 1982 United Nations Convention on the Law of the Sea (UNCLOS) in 2004. According to Annex II of UNCLOS, the particulars of the outer limits of the extended continental shelf beyond 200 nautical miles shall be submitted to the Commission on the Limits of the Continental Shelf (CLCS) within a period of ten years after ratification. To acquire the necessary data for delineating the extended continental shelf, the Continental Shelf Project of the Kingdom of Denmark was launched by the Ministry of Higher Education and Science in cooperation with the Government of the Faroe Islands and the Government of Greenland (Marcussen et al. 2004; Marcussen \& Heinesen 2009).

Five partial submissions have been submitted by the Kingdom of Denmark regarding areas north of the Faroe Islands in 2009, south of the Faroe Islands in 2010, south of Greenland in 2012, north-east of Greenland in 2013 and north of Greenland in 2014 (Fig. 1).

\section{The area north of the Faroe Islands}

North of the Faroe Islands, the extinct Ægir sea-floor spreading ridge is a prominent feature of the continental margin (Figs 1, 2). The initial opening of the North Atlantic occurred along the Ægir Ridge with active sea-floor spreading in the Eocene and Oligocene. Subsequent thermal subsidence of the oceanic crust resulted in the formation of the Northern Deep with a sediment accumulation of up to $3 \mathrm{~km}$.
The CLCS examined the partial submission regarding the area north of the Faroe Islands between 2012 and 2014 and gave special attention to: (1) the morphological continuation of the Ægir Ridge and (2) the continuity of sediments throughout the Northern Deep. In a strict morphological sense, the land mass of the Faroe Islands is connected to the Faroe-Iceland Ridge (Fig. 2). Furthermore, the Faroe-Iceland Ridge coalesces with and is morphologically linked to the Ægir Ridge. This means that the Ægir Ridge is morphologically continuous with the rest of the continental margin

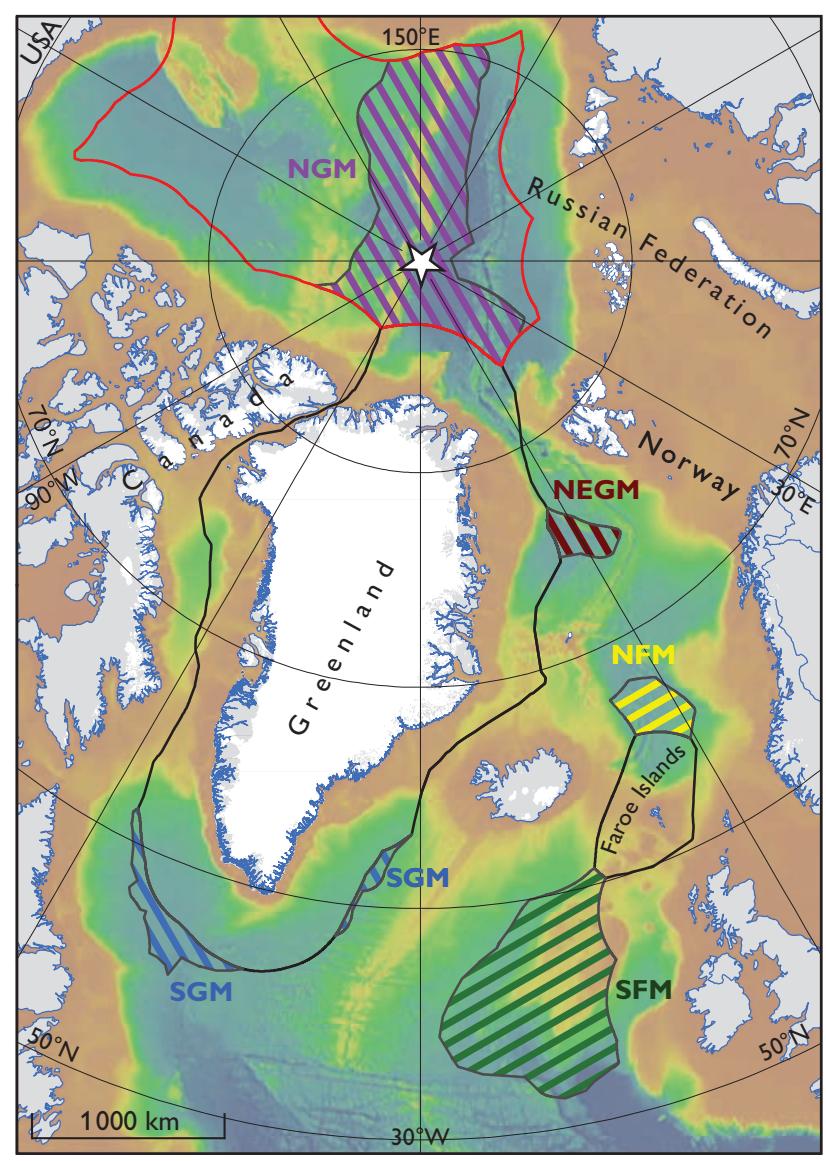

Fig. 1. The five partial submissions of the Kingdom of Denmark. Red line: The 200 nautical mile limit of the five Arctic coastal states in the Arctic Ocean. NEGM: North-east Greenland Margin. NFM: North Faroes Margin, NGM: North Greenland Margin. SFM: South Faroes Margin. SGM: South Greenland Margin. Colour scale: see Fig. 3. 


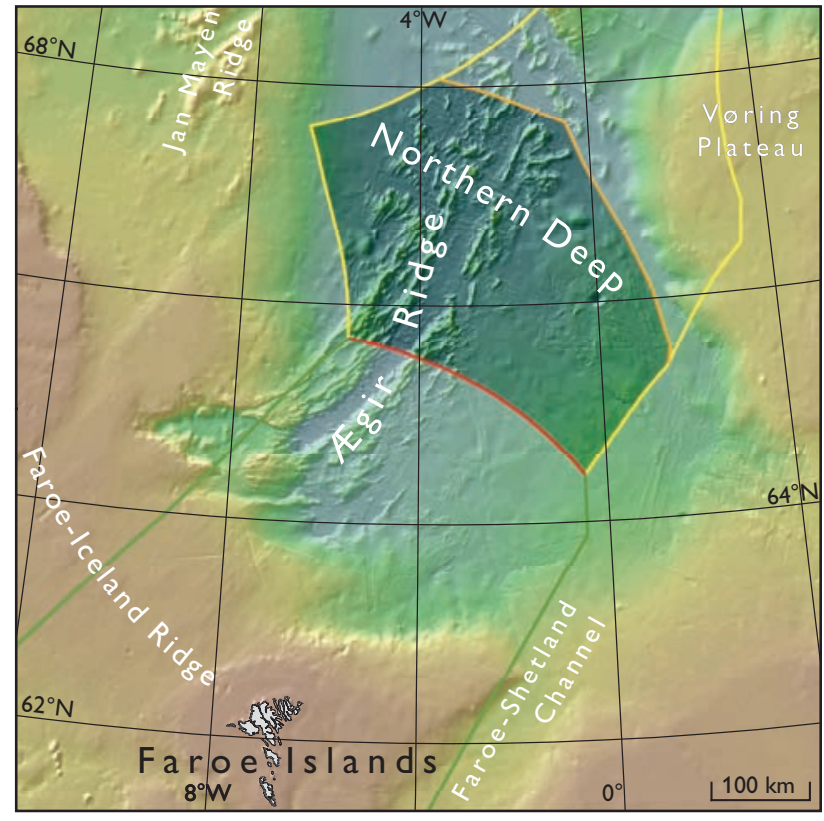

Fig. 2. The Northern Continental Shelf of the Faroe Islands showing the submission area. The continental shelf beyond 200 nautical miles in the area north of the Faroe Islands, as delineated in the submission, amounts to $87792 \mathrm{~km}^{2}$ in area and is highlighted. Green: agreed maritime boundaries within 200 nautical miles. Red: Faroese 200 nautical mile limit. Yellow: Iceland's and Norway's 200 nautical mile limits. Orange: outer limit of the continental shelf north of the Faroe Islands. Colour scale: see Fig. 3.

and lies within a common envelope of the foot of the continental slope. Thus, in the sense of UNCLOS, the Ægir Ridge is an integral part of the continental margin of the Faroe Islands, notwithstanding the tectonic and crustal differences between the two terrains (Recommendations of the Commission 2014).

The sediment thickness in the Northern Deep was documented primarily using modern seismic reflection data. Selected seismic lines were re-processed in order to improve the definition of the base of the sediments as well as the determination of the seismic velocities used for the depth conversion. The CLCS agreed with the procedure used to establish the sediment thickness, i.e. the methodology of depth conversion and the seismic interpretations. However, the CLCS initially disagreed with the method by which the Kingdom of Denmark demonstrated sedimentary continuity throughout the Northern Deep. To satisfy the CLCS, additional seismic lines, a sediment thickness map and gravity maps were provided and subsequently deemed sufficient for this purpose.

In March 2014, the CLCS adopted the recommendations regarding the partial submission north of the Faroe Islands. The Commission agreed with the determination of the fixed points establishing the outer limits of the continental shelf north of the Faroe Islands as originally listed in the submission.

\section{The area north of Greenland}

The Lomonosov Ridge is a sliver of continental crust that extends for a distance of almost $1800 \mathrm{~km}$ across the Arctic Ocean (Fig. 3). The ridge is 45 to $200 \mathrm{~km}$ wide, mostly flat-topped to slightly rounded at its crest and rises from water depths of more than $4300 \mathrm{~m}$ in the adjacent basins to typically 1000 to $1300 \mathrm{~m}$. The shallowest part of the ridge is found towards Greenland. The Lomonosov Ridge was separated from the Barents and Kara shelves during the Paleocene ( 55 to $60 \mathrm{Ma}$ ), when sea-floor spreading started to open the Eurasia Basin. This process continues today along the ultraslow-spreading Gakkel Ridge. The geological development of the Amerasia Basin is not well understood, but most authors agree that the Alpha and Mendeleev Ridges in that basin comprise a large igneous province of Cretaceous age (e.g. Jackson et al. 1986) and that sea-floor spreading has occurred in the Canada Basin (e.g. Grantz et al. 1998).

The Lomonosov Ridge is morphologically continuous with the Lincoln Shelf north of Greenland and furthermore shares geological characteristics with the land mass of Greenland. These geological characteristics are based on evidence for continuous continental crust (Jackson et al. 2010), similar lithologies and ages of rocks sampled from the flanks of the ridge compared to rocks of the adjacent land masses, and a common tectonic history. In the sense of UNCLOS, this means that the Lomonosov Ridge is a submarine elevation that is a natural component of the continental margin of Greenland and therefore the extended continental shelf north of Greenland extends across the Arctic Ocean to the 200 nautical mile line from Russia (Executive Summary 2014).

Facing the Amerasia Basin, the Lomonosov Ridge is morphologically amalgamated with the Alpha and Mendeleev Ridges and the Chukchi Borderland, which together are regarded as one complex but coherent morphological sea-floor high relative to the adjacent deep ocean floor within the Eurasia and Amerasia Basins. That is, all of this complex sea-floor high lies within a common envelope of the foot of the continental slope. However, the existing geological data for some of the individual sea-floor highs are insufficient to prove that they share geological characteristics with the Greenland land mass. For this reason, and in accordance with UNCLOS, the extended continental shelf, based on the Alpha and Mendeleev Ridges and the Chukchi Borderland, is constrained to a distance of 350 nautical miles from the territorial sea baseline of Greenland (Executive Summary 2014). 


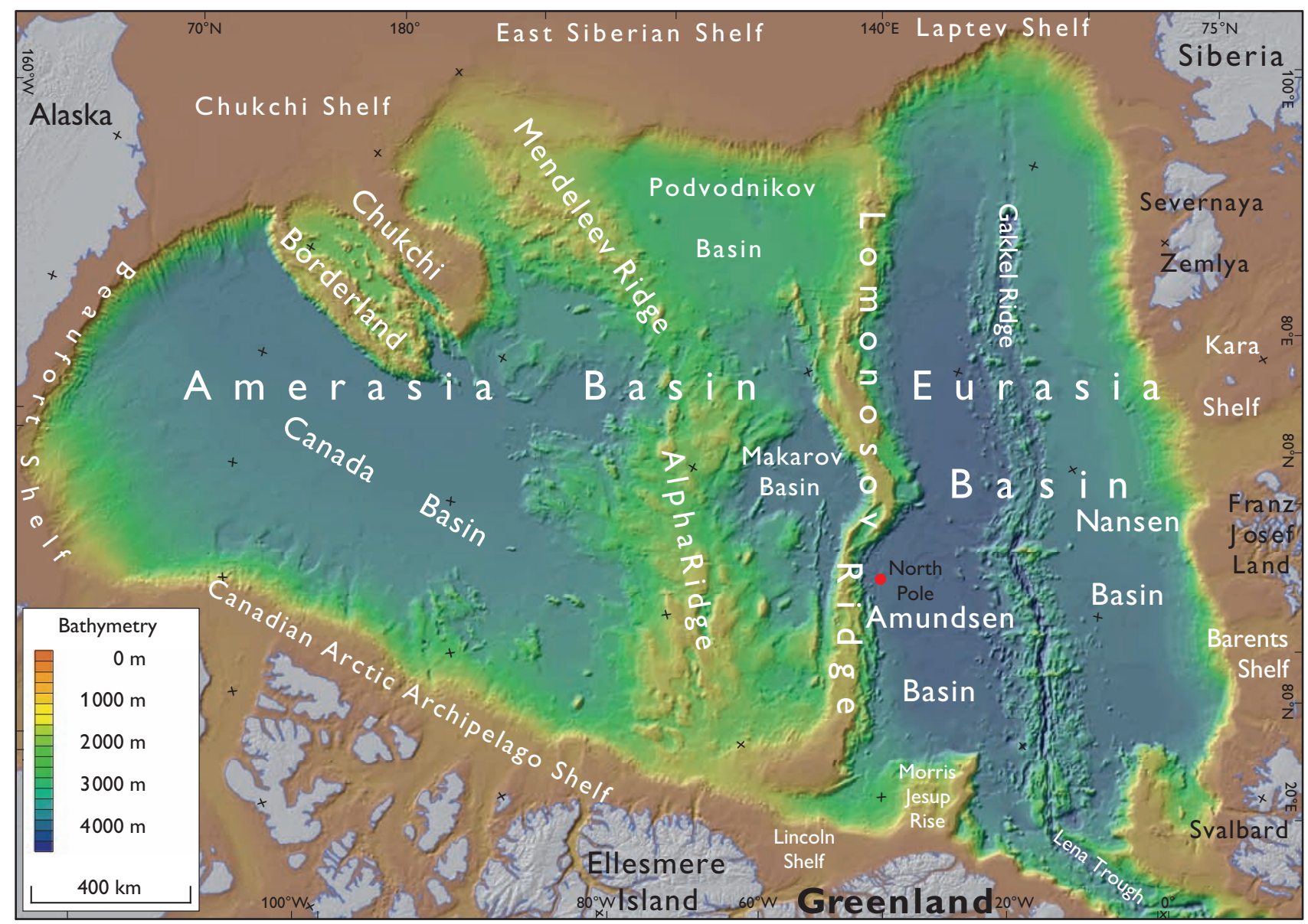

Fig. 3. Bathymetric map showing the main features of the Arctic Ocean.

By analogy with the Ægir Ridge north of the Faroe Islands, bathymetric and morphological data show that the Gakkel Ridge coalesces with the continental slope north of Greenland. The oceanic, sea-floor-spreading characteristics of the Gakkel Ridge differ geologically from the continental crust of Greenland; hence the extended continental shelf based on the Gakkel Ridge cannot exceed 350 nautical miles from the territorial sea baseline of Greenland (Executive Summary 2014).

Published seismic data from the Amundsen Basin north of Greenland (Weigelt \& Jokat 2001) indicate the presence of sediments of sufficient thickness (i.e. at least $1200 \mathrm{~m}$ ) for use in extending the continental shelf. For this reason, a purpose-built seismic acquisition system was developed (Hopper et al. 2012) that could operate in the Arctic sea ice and at sub-zero temperatures. To locate the most promising regions for seismic data acquisition, a sediment thickness map was derived from gravity inversion (Døssing et al. 2014). This study was based on the LOMGRAV airborne gravity data (Døssing et al. 2013).

Three GEUS LOMROG expeditions were carried out in 2007, 2009 and 2012 to acquire seismic data in the Arctic
Ocean. However, ice conditions only allowed for a maximum streamer length of $300 \mathrm{~m}$, which is too short to extract velocities from the seismic reflection data. For this reason, sonobuoys were deployed along the profiles to record the seismic energy at larger offsets of up to $34 \mathrm{~km}$. Ray-tracing modelling was then used to obtain velocity models of sediments in the Amundsen Basin. The velocities show little scatter (Fig. 4). Assuming normal compaction, the data points can be approximated by an exponential function of instantaneous slowness versus burial depth (Al-Chalabi 1997) using reduced major axis regression techniques. The velocity-depth relationship obtained from this approach is shown in Fig. 4 and can be used to convert the sediment thickness from time to depth.

The seismic reflection lines surveyed were generally less than $50 \mathrm{~km}$ long and focused on regions that were more than 60 nautical miles away from the Lomonosov Ridge. As the CLCS requires the documentation of sediment continuity, supplementary data had to be used. In ice-covered areas gravity data can supplement a sparse seismic database. For this reason, the results of the gravity inversion (Døssing $e t$ 


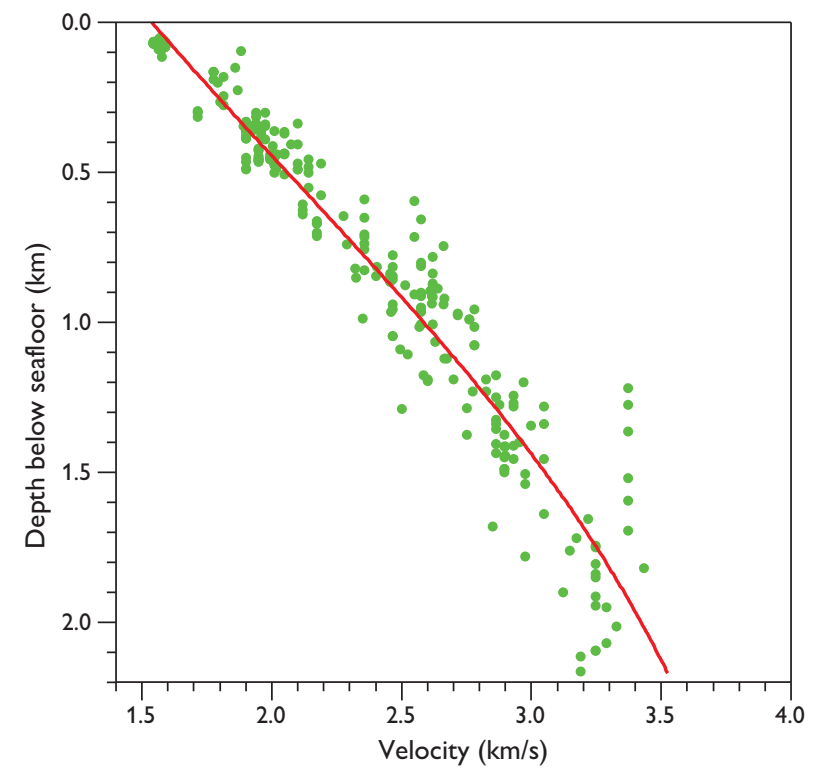

Fig. 4. Sediment velocities in the Amundsen Basin obtained from ray-tracing of the sonobuoy recordings from the three GEUS LOMROG expeditions. Green circles show individual data points; the red line indicates an approximation obtained from reduced major axis regression techniques.

al. 2014) were used to document continuity of the sediments supported by additional subbottom profiler and seismic reflection data.

\section{Concluding remarks}

The Continental Shelf Project of the Kingdom of Denmark mapped five areas relevant to extended continental shelf beyond 200 nautical miles. The project gathered bathymetric, geodetic, geological and geophysical data to compile the submission documents required by the CLCS. Despite difficult logistics, challenging climatic conditions and permanent ice cover in some of the five areas, the project was completed within the initially allocated budget of 330 million DKK ( 44 million $€$ ) and the given time frame.

Large data sets have been acquired in the five submission areas and key results have been or will be published in scientific journals. Particularly valuable are the datasets in the Arctic Ocean as this remains a poorly studied frontier region. Furthermore, the project was able to support other science projects by sharing logistics, in particular by providing access to icebreakers. The results could not have been achieved without extensive international cooperation. Due to the modus operandi of the CLCS, recommendations for the latest submission north of Greenland cannot be expected before the middle of the next decade. It represents a significant challenge to keep both data and knowledge within the project updated and state of the art.

\section{References}

Al-Chalabi, M. 1997: Instantaneous slowness versus depth functions. Geophysics 62, 270-273.

Døssing, A., Hopper, J.R., Olesen, A.V., Rasmussen, T.M. \& Halpenny, J. 2013: New aero-gravity results from the Arctic: Linking the latest Cretaceous-early Cenozoic plate kinematics of the North Atlantic and Arctic Ocean. Geochemistry, Geophysics, Geosystems 14, 4044-4065.

Døssing, A., Hansen, T.M., Olesen, A.V., Hopper, J.R. \& Funck, T. 2014: Gravity inversion predicts the nature of the Amundsen Basin and its continental borderlands near Greenland. Earth and Planetary Science Letters 408, 132-145.

Executive Summary 2014: Partial Submission of the Government of the Kingdom of Denmark together with the Government of Greenland to the Commission on the Limits of the Continental Shelf - The Northern Continental Shelf of Greenland. http://www.un.org/depts/los/clcs_ new/submissions_files/dnk76_14/dnk2014_es.pdf

Gernigon, L., Gaina, C., Olesen, O., Ball, P.J., Péron-Pinvidic, G. \& Yamasaki, T. 2012: The Norwegian Basin revisited: from continental breakup to spreading ridge extinction. Marine and Petroleum Geology 35, $1-19$.

Grantz, A. et al. 1998: Phanerozoic stratigraphy of Northwind Ridge, magnetic anomalies in the Canada basin, and the geometry and timing of rifting in the Amerasia basin, Arctic Ocean. Geological Society of America Bulletin 110, 801-820.

Hopper, J.R., Trinhammer, P., Marcussen, C. \& Funck, T. 2012: Acquisition of seismic data in ice filled waters. American Geophysical Union, Fall Meeting 2012, abstract \#C13E-0680.

Jackson, H.R., Forsyth, D.A. \& Johnson, G.L. 1986: Oceanic affinities of the Alpha Ridge, Arctic Ocean. Marine Geology 73, 237-261.

Jackson, H.R., Dahl-Jensen, T. \& the LORITA working group 2010: Sedimentary and crustal structure from the Ellesmere Island and Greenland continental shelves onto the Lomonosov Ridge, Arctic Ocean. Geophysical Journal International 182, 11-35.

Marcussen, C. \& Heinesen, M. 2010: The Continental Shelf Project of the Kingdom of Denmark - status at the beginning of 2010. Geological Survey of Denmark and Greenland Bulletin 20, 51-54.

Marcussen, C., Christiansen, F.G., Dahl-Jensen, T., Heinesen, M., Lomholt, S., Møller, J.J. \& Sørensen, K. 2004: Exploring for extended continental shelf claims off Greenland and the Faroe Islands - geological perspectives. Geological Survey of Denmark and Greenland Bulletin 4, 61-64.

Recommendations of the Commission on the Limits of the Continental Shelf in regard to the partial Submission made by the Government of Denmark together with the Government of the Faroes in respect of the Continental Shelf North of the Faroe Islands on 29 April 2009. Adopted by the Commission, with amendments, on 12 March 2014. http://www. un.org/depts/los/clcs_new/submissions_files/dnk28_09/2014_03_14_ SCDNK_REC_COM_20140521.pdf

Weigelt, E. \& Jokat, W. 2001: Peculiarities of roughness and thickness of oceanic crust in the Eurasian Basin, Arctic Ocean. Geophysical Journal International 145, 505-516.

\author{
Authors' address \\ Geological Survey of Denmark and Greenland, Øster Voldgade 10, DK-1350 Copenhagen K, Denmark. E-mail: cma@geus.dk
}

